\title{
Orogenic Au deposits of the Pohjanmaa Belt, south-western Finland: deposit model and potential Co-source
}

\author{
SIMON HECTOR, CLIFFORD G. C. PATTEN AND \\ JOCHEN KOLB
}

Institute for Applied Geosciences, KIT

Presenting Author: simon.hector@kit.edu

Gold deposits in Finnish Paleoproterozoic greenstone belts share many characteristics with orogenic Au deposits worldwide. Some deposits, however, known as atypical orogenic $\mathrm{Au}$ deposits, have an anomalous enrichment in metals critical to the energy transition (e.g. $\mathrm{Cu}, \mathrm{Co}, \mathrm{Ni}$ ) in addition to $\mathrm{Au}$. The mechanisms, however, controlling metal endowment in these orogenic $\mathrm{Au}$ deposits remains still poorly understood. We investigate four orogenic Au deposits from the Pohjanmaa Belt in southwest Finland: the Laivakangas and Huhta Au-only and the Jouhineva and Kurula $\mathrm{Au}-\mathrm{Cu}-\mathrm{Co}$ deposits. These deposits are hosted by the same lithologies, show similar structural control and formed under similar PT conditions in the lower amphibolite facies. The differences in metal endowment, hence, are likely controlled by different fluid and metal sources. Detailed petrographic studies show that the Pohjanmaa Belt deposits formed in several mineralizing stages at the metamorphic peak and during retrograde terrane exhumation. The hydrothermal alteration and ore mineralogy vary, but the deposits share a common evolution with an early As-S-(Co-Ni)-rich auriferous stage (Ni-Co-Fe arsenide, arsenopyrite, $\mathrm{Au} \pm$ pyrrhotite) followed by a $\mathrm{Cu}-\mathrm{S}-(\mathrm{Au}-\mathrm{As})$ stage (Au, chalcopyrite \pm pyrrhotite, pyrite). Arsenopyrite thermometry yields $430-500^{\circ} \mathrm{C}$ as minimum temperature for the first hydrothermal stage. The second stage displays a hydrothermal sericite-chlorite(carbonate) alteration, indicating greenschist facies conditions. We propose identify different fluid-metal source systems representative of the different metal enrichment: (1) As-(Co-Ni)rich auriferous stage: metamorphic devolatilization of metasedimentary/-volcanic rocks with an ultramafic component or magmatic fluids; and (2) $\mathrm{Cu}-(\mathrm{Au})$ stage: metamorphic devolatilization of meta-sedimentary rocks or lower crustalmantle source. Spatial association of Co-rich atypical orogenic $\mathrm{Au}$ deposits with mafic/ultramafic meta-volcanic rocks and intrusions, and $\mathrm{Cu}$-rich atypical orogenic $\mathrm{Au}$ deposits with metasedimentary rocks let us favor a model, where fluids and metals are released by multi-stage metamorphic devolatilization during complex orogenic evolution similar to typical orogenic $\mathrm{Au}$ systems. The nature of the wall rocks at a district- to provincescale is critical for the metal endowment, which is useful for targeted exploration. Altogether, the polymetallic enrichment in atypical orogenic $\mathrm{Au}$ deposits of Finland improves the economical sustainability of the deposits and represents a potential secure source of critical metals in Europe as byproducts of Au. 